\title{
Bacterial translocation in cirrhotic rats. Its role in the development of spontaneous bacterial peritonitis
}

J M Llovet, R Bartolí, R Planas, E Cabré, M Jimenez, A Urban, I Ojanguren, J Arnal, M A Gassull
Departments of

Gastroenterology

J M Llovet

R Bartolí

R Planas

E Cabré

M A Gassull

Microbiology

M Jimenez

J Arnal

Pathology

A Urban

I Ojanguren

Hospital Germans

Trias i Pujol,

Badalona, Catalunya, Spain

Correspondence to:

Dr R Planas, Department of Gastroenterology, Hospital Universitari Germans Trias i Pujol, Carretera del Canyet $\mathrm{s} / \mathrm{n}, 08916$ Badalona, Spain.

Accepted for publication

11 March 1994.

\begin{abstract}
Bacterial translocation occurs in ascitic cirrhotic rats, but its association with ascites infection is unknown. The aim of this study was to assess the relation between bacterial translocation and ascites infection in cirrhotic rats. Male Sprague-Dawley rats were induced to cirrhosis with intragastric $\mathbf{C C l}_{4}$. Ascitic fluid, portal and peripheral blood, mesenteric lymph nodes, liver and spleen samples were cultured before death in those cirrhotic rats with less (group A) or more (group B) than 250 polymorphonuclear neutrophils $/ \mathrm{mm}^{3}$ in ascitic fluid, as well as in healthy control rats. Histological examination of jejunum, ileum, and caecum was also performed. Bacterial translocation occurred in $45 \%$ of ascitic rats (without differences between groups $A$ and $B$ ), but in $0 \%$ controls $(p=0.01)$. Bacterial translocation was associated with positive ascitic fluid culture in $60 \%$ of the cases. In all of them the same bacterial species was isolated in both mesenteric lymph node and ascitic fluid. Submucosal caecal oedema $(100 \%)$, ileal lymphangiectasia (41\%), and caecal inflammatory infiltrate $(41 \%)$ occurred in ascitic rats, the last being associated with ascitic fluid positive culture $(p=0 \cdot 04)$. These results suggests that bacterial translocation occurs frequently in ascitic cirrhotic rats, and may play a permissive, but not unique, part in a number of ascites infections. Whether histological changes seen in cirrhotic ascitic rats favour bacterial translocation remains to be elucidated.

(Gut 1994; 35: 1648-1652)
\end{abstract}

Cirrhotic patients have increased susceptibility to severe infections, mainly spontaneous bacterial peritonitis and bacteraemia. Most of them $(75 \%)$ are caused by aerobic organisms of enteric origin. ${ }^{1-3}$

In the pathogenic hypothesis for spontaneous bacterial peritonitis two complementary mechanisms have been proposed. Firstly, the passage of enteric bacteria into the bloodstream after crossing the gut barrier, ${ }^{34}$ and secondly, the inability of the systemic and local - that is, peritoneal-host defences to eradicate them. Enough data on this second mechanism are available. In fact, both hepatic reticuloendothelial system impairment ${ }^{5}$ and systemic immune alterations ${ }^{6}$ have been reported in cirrhotic patients. Moreover, a facilitating role of decreased opsonic and bactericidal activities, C3 concentrations, and protein concentration in ascitic fluid upon the appearance of spontaneous bacterial peritonitis has been shown. ${ }^{7-11}$

In animal models, gut bacteria has been proved to cross the intestinal barrier to the bloodstream in several situations. ${ }^{12} 13$ This phenomenon, known as bacterial translocation, usually occurs with those aerobic bacterial species most often responsible for spontaneous bacterial peritonitis, whereas anaerobic organisms rarely translocate. ${ }^{14}$ However, direct evidence of bacterial translocation in cirrhosis is scarce. ${ }^{15} 16$ Also, no data are available about the association between bacterial translocation and systemic infections or spontaneous bacterial peritonitis in cirrhosis despite the fact that eradication of aerobic enteric organisms, by means of selective intestinal decontamination, is effective in preventing infections in cirrhosis, especially spontaneous bacterial peritonitis. ${ }^{17-19}$

The aim of this study was to investigate the incidence of bacterial translocation in cirrhotic rats with ascites, as well as to assess the possible relation between bacterial translocation and the presence of ascitic fluid infection in those rats.

\section{Methods}

Seventy three male Sprague-Dawley rats weighing 100-175 $\mathrm{g}$ were included in the study. Animals were caged individually in a constant room temperature of $21^{\circ} \mathrm{C}$, and a $17 / 7$ hour light/dark cycle, and fed $20-25$ g/day of standard rodent chow (A04, Panlab, Barcelona, Spain). The study was conducted, in agreement with the guidelines for animal research, according to the Guide for the Care and Use of Laboratory Animals.

INDUCTION OF CIRRHOSIS

Cirrhosis was induced by giving $1.5 \mathrm{mmol} / \mathrm{l}$ phenobarbital in drinking water until the animals reached $200 \mathrm{~g}$ body weight. Then, weekly intragastric $\mathrm{CCl}_{4}$ was added, starting at a dose of $20 \mu \mathrm{l}$. Subsequent doses were adjusted based upon the change in body weight 48 hours after the last dose, according to Runyon et al. ${ }^{20} \mathrm{CCl}_{4}$ was given through an appropriate orogastric feeding tube (Popper 
TABLE I General features (mean (range)) of ascitic rats studied

\begin{tabular}{llc}
\hline & $\begin{array}{l}\text { Group } A(<250 \\
\text { polymorphonuclear } \\
\left.\text { neutrophils } / \mathrm{mm}^{3}\right)\end{array}$ & $\begin{array}{l}\text { Group B }>250 \\
\text { polymorphonuclear } \\
\left.\text { neutrophils } / \mathrm{mm}^{3}\right)\end{array}$ \\
\hline $\begin{array}{l}\text { Weeks receiving } \mathrm{CCl}_{4} \\
\text { Polymorphonuclear neutrophils in ascitic fluid }\end{array}$ & $10 \cdot 2(8-18)$ & $11 \cdot 9(7-19)$ \\
$\begin{array}{l}\left.\text { (cells } / \mathrm{mm}^{3}\right) \\
\text { Polymorphonuclear neutrophils in ascitic fluid (\%) }\end{array}$ & $\begin{array}{l}70 \cdot 5(26-180) \\
14 \cdot 4(8-17)\end{array}$ & $\begin{array}{c}722.4(280-3024) \\
22 \cdot 6(15-36)\end{array}$ \\
\hline
\end{tabular}

and Sons, New Hyde Park, NY) without general anaesthesia. When ascites was found, a fixed dose of $40 \mu \mathrm{l}$ was given weekly, throughout the study. This model, a modification of the classic experimental models of cirrhosis, ${ }^{21} 22$ has been reported to have a high incidence of spontaneous bacterial peritonitis. ${ }^{20}$

\section{STUDY DESIGN}

Ten of 73 rats were used as controls, and five were laparotomised after three doses of $\mathrm{CCl}_{4}$. Samples of stomach, jejunum, ileum, and caecum were taken for light microscopy to rule out gastrointestinal damage caused by $\mathrm{CCl}_{4}$. The remaining 58 animals were induced to cirrhosis as described above. Thirty four rats died before ascites was identified (overall mortality for the model: $58 \%$ ), none of them showing longterm intestinal damage attributable to $\mathrm{CCl}_{4}$. In 25 , death occurred before cirrhosis, probably resulting from acute hepatic $\mathrm{CCl}_{4}$ toxicity. In addition, nine rats died when cirrhosis was already established (two were found to have ascites after death with a polymorphonuclear neutrophils count higher than 250 cells $/ \mathrm{mm}^{3}$ ).

Thus, 24 cirrhotic rats with clinically evident ascites and 10 healthy controls were available for bacterial translocation assessment. Ascitic fluid was obtained by paracentesis using a sterile technique, after depilation and iodine sterilisation of the abdominal wall. The presence of more than 250 polymorphonuclear

TABLE II Bacterial isolated in mesenteric lymph nodes, ascitic fluid, and other specimen culture

\begin{tabular}{|c|c|c|c|c|}
\hline Rat & Mesenteric lymph nodes & Ascitic fluid & Portal blood & Other ${ }^{\star}$ \\
\hline 1 & E coli & $\begin{array}{l}E \text { coli } \\
\text { E faecalis }\end{array}$ & E coli & $\begin{array}{l}\text { E coli } \\
\text { E faecalis }\end{array}$ \\
\hline 2 & E coli & E coli & E coli & E coli \\
\hline 3 & E coli & $E$ coli & E coli & E coli \\
\hline 4 & E faecalis & E faecalis & E faecalis & E faecalis \\
\hline 5 & Proteus sp & E coli & $\begin{array}{l}\text { Proteus sp } \\
\text { E coli }\end{array}$ & $\begin{array}{l}\text { Froteus sp } \\
\text { E coli }\end{array}$ \\
\hline & E faecalis & $\begin{array}{l}\text { E faecalis } \\
\text { Proteus sp }\end{array}$ & $\begin{array}{l}\text { E faecalis } \\
\text { Proteus sp }\end{array}$ & E faecalis \\
\hline 6 & E coli & $\begin{array}{l}E \text { coli } \\
P \text { aeruginosa }\end{array}$ & - & - \\
\hline 7 & $\begin{array}{l}\text { E coli } \\
\text { E faecalis }\end{array}$ & - & - & - \\
\hline 8 & E coli & - & - & - \\
\hline 9 & E coli & - & - & - \\
\hline 10 & $P$ aeruginosa & - & - & - \\
\hline 11 & - & $\begin{array}{l}\text { E coli } \\
\text { Proteus } \mathrm{sp}\end{array}$ & $\begin{array}{l}E \text { coli } \\
\text { Proteus } \mathrm{sp} \\
\text { E faecalis }\end{array}$ & $\begin{array}{l}E \text { coli } \\
\text { Proteus sp } \\
\text { E faecalis }\end{array}$ \\
\hline 12 & - & $\begin{array}{l}\text { E coli } \\
\text { E faecalis } \\
\text { Proteus sp }\end{array}$ & - & - \\
\hline 13 & - & $\begin{array}{l}E \text { coli } \\
E \text { faecalis }\end{array}$ & - & - \\
\hline 14 & - & $\begin{array}{l}E \text { coli } \\
\text { Proteus } \mathrm{sp}\end{array}$ & - & - \\
\hline 15 & - & Proteus sp & Proteus sp & Proteus sp \\
\hline
\end{tabular}

*Other samples: portal and peripheral blood, liver, and spleen.

No bacteria were isolated in seven rats. neutrophils $/ \mathrm{mm}^{3}$ in the ascitic fluid was used as the diagnostic criterion for ascites infection in rats. ${ }^{20}$ Accordingly, two groups were studied: 12 ascitic rats were evaluated as soon as ascites with less than 250 polymorphonuclear neutrophils $/ \mathrm{mm}^{3}$ (group A) was identified, whereas in the remaining 12, diagnostic paracenteses were performed every 4872 hours and were studied when the polymorphonuclear neutrophils count was above 250 cells $/ \mathrm{mm}^{3}$ (group B). Only 10 rats of the second group, however, could be studied because two died before reaching this end point, and were not included despite a polymorphonuclear neutrophils count $>250$ cells $/ \mathrm{mm}^{3}$, which was found after death in one.

Bacterial translocation was defined as the presence of viable enteric organisms in mesenteric lymph nodes. ${ }^{23}$ Bacterial translocation assessment was always performed before death, and consisted of bacteriological studies of mesenteric lymph nodes, ascitic fluid, portal and peripheral blood, and abdominal viscera. In addition, histological samples of mesenteric lymph nodes, liver, spleen, jejunum, ileum, and caecum were also studied. For these purposes, a laparotomy was carried out under strict aseptic conditions and general anaesthesia (subcutaneous ketamine $\mathrm{HCl}$, atropine, and diazepam). Potential sources of secondary peritonitis were carefully searched for. Samples were obtained in the following order: ascitic fluid, portal and peripheral (inferior vena cava) blood, mesenteric lymph nodes, liver, spleen, jejunum, ileum, and caecum.

\section{LABORATORY METHODS}

Ascitic fluid cell count was performed by hand using a Neubauer camera. Blood and ascitic fluid samples were cultured by immediate inoculation into blood culture bottles (modified Castañeda medium, thioglycolate broth; Knickerbocker Lab, Barcelona, Spain), a method that has been validated in humans. ${ }^{24}$ Parenchymatous viscera were immediately cultured in brain-heart medium. Samples for histological examination were collected in $10 \%$ formaldehyde, subsequently embedded in paraffin wax, sliced in $5 \mu \mathrm{m}$ sections, and stained with haematoxylin and eosin. They were examined by light microscopy by a 'blinded' pathologist.

\section{STATISTICAL ANALYSIS}

Unless stated, results are expressed as mean (SEM) or proportion as required. Comparison of means was performed by the Student $t$ test for unpaired data or its non-parametric counterpart (Mann-Whitney test) as required. Proportions were compared by means of Fisher's exact test.

\section{Results}

Table I details the data regarding length of $\mathrm{CCl}_{4}$ exposure, polymorphonuclear 


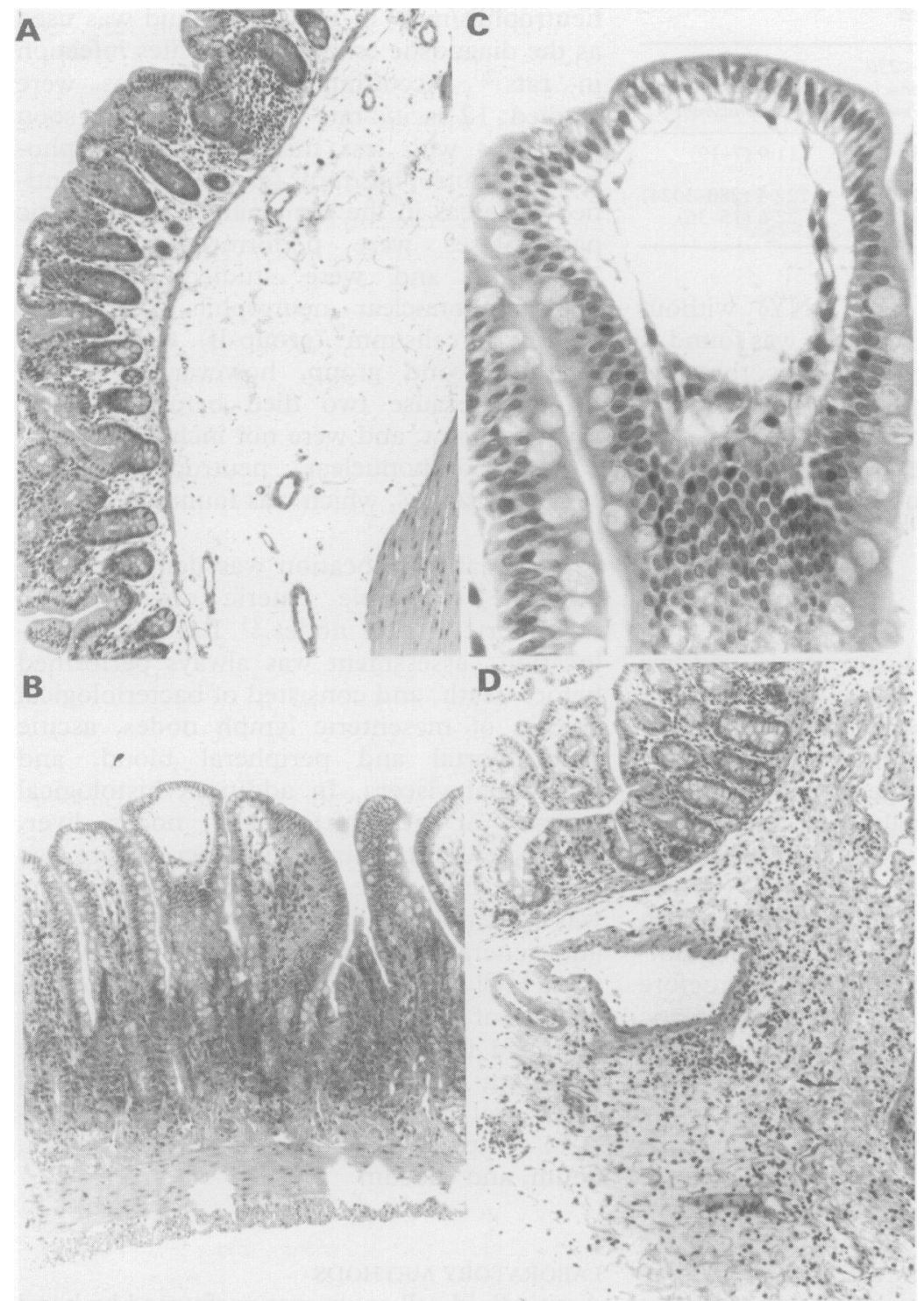

Figure 1: Histological changes seen in cirrhotic rats with ascites (haematoxylin and eosin). (A) Submucosal caecal oedema (original magnification $\times 40)$; $(B, C)$ ileal lymphangiectasia (original magnification $\times 100 ; \times 400$ ); (D) submucosal caecal inflammatory infiltrate (original magnification $\times 100$ ). of group A. Accordingly, mean polymorphonuclear neutrophils count in ascitic fluid did not differ between rats with and without positive ascitic fluid culture (514 (258) v 218 (76) cells $/ \mathrm{mm}^{3}, \mathrm{NS}$ ).

The type of micro-organisms present in mesenteric lymph nodes and ascitic fluid were compared to ascertain the possible association between bacterial translocation and ascitic fluid infection. Among the 10 rats with bacterial translocation, six showed the same bacterial species both in ascitic fluid and in mesenteric lymph nodes (Table II). In the remaining four rats, no other specimen, apart from mesenteric lymph nodes, was positive. Five of 12 ascitic rats without bacterial translocation showed positive ascitic fluid culture. In two of them the same bacteria was also cultured in portal blood.

Table II shows, in individual rats, the association between the results of ascitic fluid, portal blood, and other specimen culture and the presence or absence of bacterial translocation. The organisms isolated were all aerobes of enteric origin. The most frequent was Escherichia coli, which was obtained in $70 \%$ and $82 \%$ of positive cultures from mesenteric lymph nodes and ascitic fluid, respectively. Seventy two per cent of positive ascitic fluid cultures were polymicrobial, whereas this only occurred in $20 \%$ of the positive mesenteric lymph nodes cultures.

HISTOLOGICAL FEATURES

All histological specimens studied were normal in control rats. Likewise, no gastrointestinal damage was seen in those rats studied after three doses of $\mathrm{CCl}_{4}$.

All ascitic rats had histological evidence of cirrhosis and vascular congestion of the spleen, probably secondary to portal hypertension. About $63 \%$ of ascitic rats showed activated germinal centres of mesenteric lymph nodes $(\mathrm{p}=\mathrm{NS} v$ controls), but no relation with bacterial translocation, polymorphonuclear neutrophils count or positive culture in ascitic fluid was seen.

Three abnormal features were present in the gut of ascitic animals. These were submucosal caecal oedema (Fig 1A), which occurred in all of them $(\mathrm{p}<0.0005 v$ controls), ileal lymphangiectasia (Fig $1 \mathrm{~B}$ and $\mathrm{C}$ ), which was present in nine of 22 cases ( $p=0.017 v$ controls), and caecal inflammatory infiltrate (lymphocytic in six and mixed, lymphocytes + polymorphonuclear neutrophils, in three) was found in nine of 22 rats $(\mathrm{p}=0.017 v$ controls) (Fig 1D). The infiltrate involved the submucosal, muscular, and serosal layers in six cases and was confined to the submucosa in the remaining three. Mucosal infiltrate was not seen.

When the relation between histological findings and bacterial translocation, polymorphonuclear neutrophils count or positive ascitic fluid culture was studied, only a weak association was found between caecal inflammatory infiltrate and positive ascitic fluid culture $(p=0.04)$. 


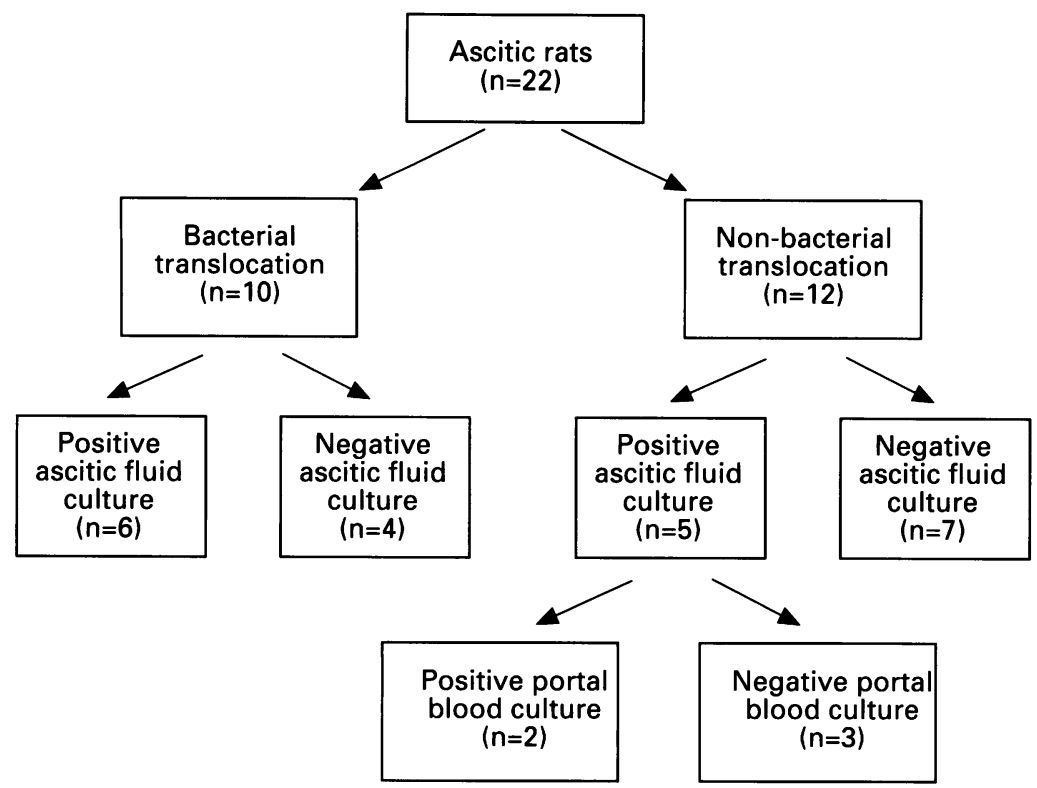

Figure 2: Possible pathogenic role of bacterial translocation in the development of ascitic fluid infection. (See text for details).
Although bacterial translocation has been widely shown to occur in rats in several situations, ${ }^{12} 13$ information about its occurrence in cirrhosis with ascites is scarce. ${ }^{1516}$ In our study, $45 \%$ of ascitic rats showed translocation of aerobic gut flora to mesenteric lymph nodes. In contrast, no control rat showed bacterial translocation. In fact, mesenteric lymph nodes in pathogen free rats and in healthy humans are sterile ${ }^{12} 25$ because bacteria either do not pass through gastrointestinal mucosa, are cleared in transit to the mesenteric lymph nodes, or are killed by macrophages in the mesenteric lymph nodes itself. 1226

The high rate of bacterial translocation found in our study, as well as in recently reported abstracts $\left(88 \%,{ }^{15} 56 \%{ }^{16}\right)$, suggests that certain factors favouring bacterial translocation may occur in ascitic rats, and probably also in human cirrhotic patients with ascites. Although they have not been evaluated in this study, some conditions associated with an experimentally shown high rate of bacterial translocation, such as intestinal bacterial overgrowth, ${ }^{27}$ portal hypertension, ${ }^{28-30}$ haemorrhagic shock, ${ }^{28} 31$ endotoxaemia, ${ }^{32}$ impaired host defence mechanisms, ${ }^{33}$ and malnutrition, ${ }^{34}$ are common in cirrhosis. ${ }^{1}$ 35-37 Particularly, endotoxaemia should be assessed in future studies, because some authors argue that endotoxin precedes and promotes bacterial translocation. ${ }^{32}$

The possibility that $\mathrm{CCl}_{4}$ induced gut damage could account for this high bacterial translocation rate seems unlikely because gastrointestinal lesion was ruled out in our study.

To our knowledge, there are no published data about the relation between bacterial translocation and spontaneous bacterial peritonitis in cirrhotic rats. In our study, no differences in the bacterial translocation rate were seen between those rats with or without ascitic fluid positive culture, suggesting that bacterial translocation is not a sine qua non condition for ascitic fluid infections, although it may play a permissive part in some cases. Nevertheless, some of the observed associations between positive culture in mesenteric lymph nodes and other samples may help to better define the role of bacterial translocation in the spontaneous bacterial peritonitis pathogenic hypothesis.

Among the 10 rats with bacterial translocation (Fig 2), six showed the same bacterial species both in mesenteric lymph nodes and ascitic fluid, supporting the hypothesis that a number of enteric bacteria finally colonising ascitic fluid reach the bloodstream through the lymphatic route. In fact, bacterial translocation to mesenteric lymph nodes has been reported to be the main mechanism of the entrance of gut bacteria to the systemic circulation in multiple experimental situations. ${ }^{1213}$ In contrast, four rats showed bacterial translocation with no other positive samples, suggesting that the presence of viable bacteria in mesenteric lymph nodes does not always point to an impending systemic infection. Thus, despite the presence of the above described factors favouring bacterial translocation, the access of 
bacteria to the bloodstream and ascitic fluid requires an impaired systemic or local (peritoneal) host defence, or both.

On the other hand, in five of 12 cases without bacterial translocation a positive ascitic fluid culture was found. Two of them showed positive cultures from portal and systemic blood and viscera. Although a positive portal culture can occur in the setting of a systemic infection, it could be speculated that the passage of gut bacteria to portal blood may be an alternative route of access for enteric bacteria to the bloodstream in cirrhosis. Interestingly, such a mechanism has already been reported in experimental models of peritoneal inflammation. ${ }^{38}$ In the remaining three rats, there is no explanation for ascitic fluid positive culture in terms of this study. Passage through other mesenteric lymph nodes, however, not harvested for culture, transient portaemia, or an extraintestinal septic focus, for example, urinary infection may account for these cases.

Two of the most conspicuous histological features found in this study, namely submucosal caecal oedema and ileal lymphangiectasia, are probably related to the presence of portal hypertension. ${ }^{29} 30$ Even though they were not statistically associated with bacterial translocation, polymorphonuclear neutrophils count or positive ascitic fluid culture, their possible role favouring the passage of gut bacteria into mesenteric lymph nodes cannot be ruled out. Caecal inflammatory infiltrate was weakly associated with positive ascitic fluid culture. It remains to be elucidated if it is a manifestation of chronic inflammation, which has been reported in experimental portal hypertension, ${ }^{29} 30$ or is related to acute peritoneal infection.

In the light of these results, it is concluded that bacterial translocation occurs frequently in ascitic cirrhotic rats and may play a permissive, but not unique, part in ascites infection. Further investigations are required to find out if the polymorphonuclear neutrophils threshold used in humans applies to cirrhotic rats, and also to discover a possible pathogenic link between the intestinal histological changes seen in this study and bacterial translocation.

Preliminary results of this study were presented at the 94th Annual Meeting of the American Gastroenterological
Association held in Boston, May 1993. This study was partly Association held in Boston, May 1993. This study was partly
supported by a grant of the FISss (No 92/0764) of the Spanish National Institute of Health.

1 Hoefs JC, Runyon BA. Spontaneous bacterial peritonitis. Disc Mon 1985; 31: 1-48.

2 Llovet JM, Planas R, Morillas R, Quer JC, Cabré E, Boix J, et al. Short-term prognosis of cirrhotics with spontaneous bacterial peritonitis: multivariate study. Am $\mathcal{F}$ Gastroentero 1993; 88: 388-92

3 Garcia-Tsao G. Spontaneous bacterial peritonitis. Gastroenterol Clin North Am 1992; 21: 257-75.

4 Runyon BA. Pathogenesis and diagnosis of spontaneous bacterial peritonitis in cirrhosis. In: Rodés J, Arroyo V eds. Therapy in liver disease. Barcelona: Doyma, 1992 eds. Thera

5 Rimola A, Soto R, Bory P, Arroyo V, Piera C, Rodes J. Reticuloendothelial system phagocytic activity in cirrhosis and its relation to bacterial infections and prognosis. Hepatology 1984; 4: 53-8.

Hepatology 1984; 4: 53-8.
6 Rabinovitz M, Gavaler J, Kumar S, Kajani M, Van Thiel V. Role of serum complement, immunoglobulins and cellmediated immune system in the pathogenesis of spontaneous bacterial peritonitis. Dig Dis $S_{C i} 1989 ; 34$ t547-52.

7 Runyon BA. Low protein concentration ascitic fluid is predisposed to spontaneous bacterial peritonitis. Gastroenterology 1986; 96: 1343-6.
8 Titó LL, Rimola A, Ginès P, Llach J, Arroyo V, Rodes J. Recurrence of spontaneous bacterial peritonitis in cirrhosis: frequency and predictive factors. Hepatology 1988; 8: $27-31$.

9 Andreu M, Solà R, Sitges-Serra A, Alia C, Gallen M, Vila $\mathrm{C}$, et al. Risk factors for spontaneous bacterial peritonitis in cirrhotic patients with ascites. Gastroenterology 1993; 104: $1133-8$.

10 Runyon BA. Patients with deficient ascitic fluid opsonic activity are predisposed to spontaneous bacterial periactivity are predisposed to spontan
tonitis. Hepatology 1988; 8: $632-5$.

11 Akalin HE, Laleli Y, Telatar H. Bactericidal and opsonic activity of ascitic fluid from cirrhotic and noncirrhotic patients. F Infect Dis 1983; 147: 1011-7.

12 Wells C, Maddaus M, Simmons R. Proposed mechanisms for the translocation of intestinal bacteria. Rev Infec Dis 1988; 10: 958-79.

13 Alexander JW, Boyce S, Babcock G, Gianotti L, Peck M, Dunn D, et al. The process of microbial translocation. Ann Surg 1990; 212: 496-510.

14 Steffen EK, Berg RD, Deith EA. Comparison of translocation rates of various indigenous bacteria from gastrointestinal tract to mesenteric lymph node. F Infect Dis 1988; 157: 1032-8.

15 Runyon BA, Squier SU. Translocation of gut bacteria of cirrhotic rats to mesenteric lymph nodes may partially explain the pathogenesis of spontaneous bacterial peritonitis. Hepatology 1991; 14: $91 \mathrm{~A}$

16 Garcia-Tsao G, Lee FY, Barden GE, West AB, Erickson C. Bacterial translocation is increased in experimental cirrhosis. Gastroenterology 1993; 104: A905.

17 Ginès P, Rimola A, Planas R, Vargas V, Marco F, Almela $M$, et al. Norfloxacin prevents spontaneous bacterial peritonitis recurrence in cirrhotics: results of a double-blind, tonitis recurrence in cirrhotics: results of a double-blind,

18 Rimola A, Bory F, Terés J, Perez-Ayuso RM, Arroyo V, Rodés J. Oral, nonabsorbable antibiotics prevent infection Rodés J. Oral, nonabsorbable antibiotics prevent infection in cirrhotics with ga

19 Soriano G, Guarner C, Teixidó M, Such J, Barrios J Enriquez Vilardell F. Selective intestinal decontamination prevents spontaneous bacterial peritonitis. Gastroenterology 1991; 100: 477-81

20 Runyon BA, Sugano S, Kanel G, Mellencamp M. A rodent model of cirrhosis, ascites, and bacterial peritonitis. Gastroenterology 1991; 100: 489-93.

21 Proctor E, Chatamra K. High yield micronodular cirrhosis in the rat. Gastroenterology 1982; 83: 1183-90.

22 Mellencamp M, Preheim L. Pneumococcal pneumonia in a rat model of cirrhosis: effects of cirrhosis on pulmonary defence mechanisms against Streptococcus pneumoniae. finfect Dis 1991; 163: 102-8.

23 Berg RD, Garlington AW. Translocation of certain indigenous bacteria from the gastrointestinal tract to the digenous bacteria from the gastrointestinal tract to the
mesenteric lymph nodes and other organs in gnotobiotic mesenteric lymph nodes and other organs in gno

24 Runyon BA, Canawati H, Akriviadis E. Optimization of ascitic fluid culture technique. Gastroenterology 1988; 95: 1351-5.

25 Deitch EA. Simple intestinal obstruction causes bacteria translocation in man. Arch Surg 1989; 124: 699-701.

26 Wells C, Maddaus M, Simmons R. Role of the macrophage in the translocation of intestinal bacteria. Arch Surg 1987; 122: 48-52.

27 Steffen E, Berg R. Relationship between caecal population levels of indigenous bacteria and translocation to mesenteric lymph nodes. Infect Immun 1983; 39: 1252-9.

28 Sorell WT, Quigley EM, Jin G, Johnson TJ, Rikkers LF. Bacterial translocation in portal-hypertensive rat: studies Bacterial translocation in portal-hypertensive rat: studies
in basal conditions and on exposure to haemorrhagic in basal conditions and on exposure to
shock. Gastroenterology 1993; 104: 1722-6.

29 Duda P, Vauthey JN, Gertsch Ph, Wheatley AM. Bacterial translocation in portally hypertensive rats. [Abstract.] f Hepatol 1992; 16: S40.

30 Garcia-Tsao G, Albillos A, Barden GE, West AB. Bacteria translocation in acute and chronic portal hypertension. Hepatology 1993; 17: 1081-5.

31 Redan J, Rush B, McCullough J, Machiedo G, Murphy T, Dikdan G, et al. Organ distribution of radiolabelled enteric Escherichia coli during and after haemorrhagic shock. Ann Surg 1990; 211: 663-8.

32 Deitch E, Berg R, Specian R Endotoxin promotes the translocation of bacteria from the gut. Arch Surg 1987; 122: 185-9.

33 Debure A, Colombel J, Cywiner-Golenzer C, Rouchette J, Hoang C, Dellagi K, et al. Role of the digestive tract immune system in the control of bacterial translocation in gnotoxenic mice. Gastroenterol Clin Biol 1986; 10: 712-7.

34 Alexander JW. Nutrition and translocation. FPEN 1990; 14 (suppl): 171-4S

$35 \mathrm{Lal} \mathrm{D,} \mathrm{Gorbach} \mathrm{S,} \mathrm{Levitan} \mathrm{R.} \mathrm{Intestinal} \mathrm{microflora} \mathrm{in}$ patients with alcoholic cirrhosis: urea-splitting bacteria and neomycin resistance. Gastroenterology 1972; 62: 275-9.

36 Abad-Lacruz A, Cabré E, González-Huix F, FernandezBañares F, Esteve-Comas M, Planas R, et al. Routine tests of renal function, alcoholism and nutrition improve the prognostic accuracy of Child-Pugh score in non-bleeding prognostic accuracy of Child-Pugh score in non-bleeding

advanced cirrhotics. Am $\mathcal{F}$ Gastroenterol 1993; 88: 382-7. Endotoxin and bacteria in portal blood. Gastroenterology Endotoxin and bacteri

38 Mainous M, Tso P, Berg R, Deitch E. Studies of route, magnitude, and time course of bacterial translocation in model of systemic inflammation. Arch Surg 1991; 126: 33-7. 